\title{
The Determinants of Capital Structure: A Comparative Study between Sharia and Non-Sharia Manufacturing Companies on Indonesia Stock Exchange (IDX)
}

\author{
Imam Akbar Ilham Arif ${ }^{a *}$ and Muhammad Umar Mai ${ }^{\mathrm{b}}$

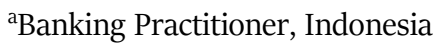 \\ ${ }^{\mathrm{b}}$ Associate Professor, Department of Islamic Finance and Banking, Politeknik Negeri Bandung, \\ Indonesia
}

Received o8 October 2019; accepted 30 January 2020

\begin{abstract}
The Decree of Financial Service Authority (Bapepam LK) II K.1 regarding Criteria and Issuance of Sharia Securities List Number KEP-208/BL/2012 stipulates that any companies which are classified as sharia in IDX may not have total interest- based debt over $45 \%$, compared to their total assets. It is predicted to give certain impact to those companies in determining the amount of debt ratio and the factors influencing it. This current research has two objectives; (1) to compare debt ratio which is measured by Book Leverage and (2) to compare the impact of Size, Tangibility, Profitability, and Gross Domestic Product toward Book Leverage. This study was conducted on go public manufacturing companies on IDX in the period of 2011-2017. The companies were divided into two groups; the sharia and the non-sharia. The results show that sharia companies significantly have smaller Book Leverage than the non-sharia one. Size, Tangibility, and Profitability have significant impacts toward Book Leverage of both groups. Meanwhile, Gross Domestic Product only gives significant impact on the Book Leverage of non-sharia manufacturing companies.
\end{abstract}

\section{KEYWORDS}

Capital structure

Sharia-criteria

Non-sharia criteria

\section{INTRODUCTION}

Every company has long-term goals which are to maximize the prosperity of its shareholders and to realize the policy of capital structure. In order to reach those goals, the capital structure decision becomes one of the most important decisions to make (Varun, 2014). It is one of the functions of financial management which must be executed properly in every company (Copeland \& Weston, 1988). A correct and accurate investment decision will result on higher profit or return as indicated by positive NPV (Net Present Value). It can be achieved if the company is funded by an optimal capital structure.

An optimal capital structure can be achieved by various ways, one of which is by combining the equity and optimal debt financing. It also can be achieved by minimizing the Weighted Average

*Corresponding Author: imamakbarilhamarif@gmail.com; doi: 10.35313/ijabr.voio.67 
Cost of Capital (WACC) (Damodaran, 2012). However, a number of empirical evidences show that the statement may not fully consider the complexity between the set of endogenous variables, which has been known to influence the capital structure decision (Pawet, Dmytro, \& Ryszard, 2018). According to Agency theory, the management, as the agent of company's shareholders, tends to behave opportunistically. This opportunistic behavior is often indicated by management's dislike on high-risk investment projects along with their funding choices. The management tends to invest on low-risk projects. As the consequence, the company just obtains low profit ('high risk high return, low risk low return'). It also happens in choosing the source to fund the projects. The management tends to choose retained earnings as the source of fund since it has the lowest risk. It is supported by Pecking Order theory which suggests using low-risk source of fund as retained earnings (Myers, 2001).

However, the Agency theory has different opinion. This theory recommends a company to use higher-risk funding for its capital structure, such as debt (Jensen \& Meckling, 1976). This suggestion is much supported by other various theories, such as Balance theory and Trade Off theory. The theories say that debt can continue to increase as long as its benefit is greater than its interest expenses, but it is not static (Myers, 2001). The management does not need to continuously use debt as the funding source. They need to see whether the benefit of the debt is still greater than the return and its interest, if not, then the management should stop using debt and look for other sources of fund.

Various studies also agree with this opinion. Agency theory-based capital structure with debt can actually increase profitability. It is shown by company values listed on Indonesia Stock Exchange in the period of 2008-2012 (Hamidy, Wiksuana, \& Artini, 2014). The application of debt and retained earnings as funding sources as stated in Trade Off theory and Pecking Order theory has been applied in the capital structure of manufacturing companies in India (Saurabh \& K., 2015). Moreover, the low-risk source of fund as the Pecking Order theory suggested turns out to be more applied in non-financial companies in Estonia (Raul, 2008).

In spite of many evidences showing the application of the above theories in various companies' managements, the selection of policies regarding the capital structure based on those theories remains unsolved. This condition becomes quite a challenge for manufacturing companies listed on Indonesia Stock Exchange. Manufacturing companies in Indonesia are divided into two big groups; sharia and non-sharia based companies. They can be distinguished through Indonesian Sharia Stock Index (ISSI) on Indonesia Stock Exchange. The criteria used to distinguish these two groups refer to the decrees of National Sharia Council (DSN) MUI and Financial Service Authority (Bapepam LK) regarding Sharia Securities List. As for sharia-based manufacturing companies, it also refers to the decree of Financial Service Authority (Bapepam LK) II K.1 regarding Criteria and Issuance of Sharia Securities List Number KEP-208/BL/2012.

DSN MUI and Bapepam LK set the quantitative requirement for financial ratio regarding the total amount of interest-based or usury-based debt for not more than $45 \%$. It is based on Imam AlGhazali who claims that the debt should not be greater than the capital. Meanwhile, the concept used to determine the percentage combination between capital and usury-based debt is tafriq alhalal 'al-haram by separating halal and haram assets (Baharudin \& Sy, 2015). It becomes one of the requirements to be fulfilled by all sharia manufacturing companies in Indonesia.

At the same time, company's management still gets difficulty in determining policies regarding the use of funding source. The management must be able to determine the appropriate policies for company funding source in order to optimize the capital structure as well as maximize the company performance which can be depicted from company value. Sharia manufacturing companies are no exception. They even have challenge to limit the interest-based debt by $45 \%$. 
Based on the above background and literature review, this research is compulsory to be conducted in order to determine the impact of implementing DSN MUI and Bapepam LK regulations on the capital structure formation of sharia and non-sharia manufacturing companies. Besides, it is also aimed to discover the impact of determinant factors such as Size, Tangibility, PROF, and GDP on capital structure formation of each group of companies.

\section{MODEL AND RESEARCH HYPOTHESES}

\section{Capital Structure of Sharia and Non-Sharia Manufacturing Companies}

The components of capital structure include long-term debt, common capital stock, preferred capital stock, capital surplus, and accumulated retained earnings (Kieso, Weygandt, \& Warfield, 2010). DSN MUI and Bapepam LK's quantitative requirement regarding financial ratio becomes one of the requirements to fulfill by every sharia manufacturing company in Indonesia. Another requirement is that the total amount of interest and other non-halal incomes is not more than $10 \%$ compared to total revenue and other incomes. The previous definition shows that there is an indicator of capital structure on sharia and non-sharia manufacturing companies in the form of BLEV (Book Leverage). However, due to some limitations set on sharia companies, it is suspected that there is a significant difference between these two.

$\mathrm{H}_{1}$ : There is a significant difference between the capital structure of sharia and non-sharia manufacturing companies

\section{Size and Capital Structure}

According to (Yildirim, Masih, \& Bacha, 2018), size of a company becomes one of capital structure determinants, as profitability and growth possibility. It gives consistent result in relation to capital structure. However, it depends on which capital theory to be referred to. The Trade-Off theory says that this relation can be expected because the bigger the company, the lesser the risk of bankruptcy it will face. In short, this company is too big to go bankrupt. However, the bigger the company, the more unstable the cash flow will be. It is caused by diversification effect which often happens (Titman \& Wessels, 1988).

$\mathrm{H}_{2}$ : Size of company gives significant impact on the capital structure of sharia and non-sharia manufacturing companies

\section{Tangibility and Capital Structure}

Company's tangibility becomes one of determinants which also gives consistent result toward capital structure (Yildirim et al., 2018). The opinion of (Ahmed, 2007) states that debt must be supported by assets, which means a company cannot have more debt than its tangible assets. Moreover, it also implies that a company which has more assets than its tangible assets will obtain higher debt and vice versa. However, (Thabet \& Hanefah, 2014) find that there is no significant relation between tangibility and leverage. There is no significant evidence which proves that a company considers its fixed assets when doing financing activities. 
$\mathrm{H}_{3}$ : Tangibility gives significant impact on the capital structure of sharia and non-sharia manufacturing companies

\section{Profitability and Capital Structure}

There is a close relation between profitability and capital structure. Literatures even say that profitability can be one of the bases of leverage that can be justified. This is in line with (Yildirim et al., 2018) who claim that profitability is one of the most tested determinants of capital structure used in academic study. Capital structure theories explain the relation between profitability and leverage. According to Trade-Off theory, a more profitable company tends to have more debt since it will be more beneficial in relation to tax policy (Myers, 2001). It is because the company can have better opportunity to protect more profits by using the tax of the debt. Another positive side can also be assumed from the fact that the company gets benefit of paying cheaper debt (Yildirim et al., 2018).

$\mathrm{H}_{4}$ : Profitability gives significant impact on the capital structure of sharia and non-sharia manufacturing companies

\section{Gross Domestic Product (GDP) and Capital Structure}

A research by (De Jong, Kabir, \& Nguyen, 2008) shows that the higher the economic growth, the higher the tendency of a company to utilize debt to finance its new investment. However, according to Pecking Order theory, the growth of GDP is associated with more profits for the company; it enables the company to use more internal capital than financing the debt. The academic studies have found various results regarding the relation between GDP and capital structure (Yildirim et al., 2018).

$\mathrm{H}_{5}$ : GDP gives significant impact on the capital structure of sharia and non-sharia manufacturing companies

\section{Development of the Research Model}

Figure 1 explains how determinant factors namely Size, Tangibility, Profitability, and Gross Domestic Product are suspected to give impacts on capital structure of both sharia and non-sharia manufacturing companies. Then, it also sees whether there are differences of capital structure and determinant factors on both groups of companies. 


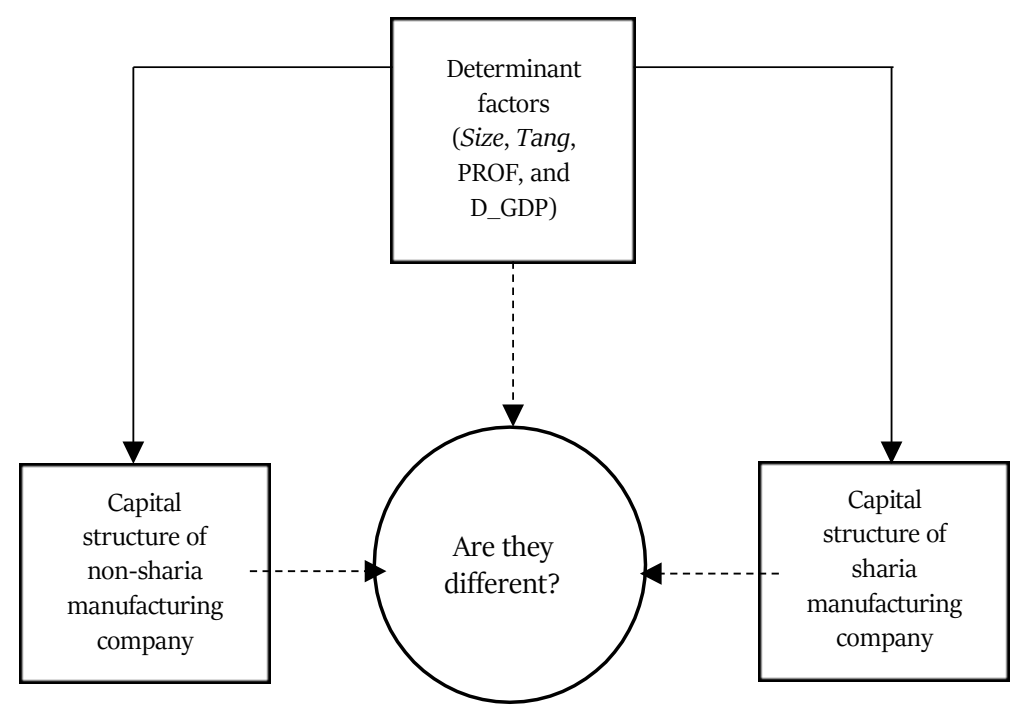

Figure 1. Proposed model

\section{RESEARCH METHODS}

\section{Population and Sample}

The populations of this research were all manufacturing companies listed on the Indonesia Stock Exchange successively from 2011 to 2017. The samples were determined by purposive sampling method under the criteria: 1) the companies can be identified as sharia or non-sharia according to DSN MUI and Bapepam LK regulations regarding Sharia Securities List, 2) the companies submitted their annual, financial, and performance reports from 2011 to 2017, and 3) the companies have all analyzed variables.

\section{Research Model}

The model of the research was developed by following these steps: 1) examining the difference of book leverage values of sharia and non-sharia manufacturing companies, 2) analyzing the effect of profitability, company size, tangibility, and GDP growth on book leverage of sharia manufacturing companies, 3) analyzing the effect of profitability, company size, tangibility, and GDP on book leverage of non-sharia manufacturing companies, and 4) analyzing the significance, aim, and regression coefficient between the results of 2) and 3).

Independent sample t-test was used to discover and analyze the different values of book leverage of sharia and non-sharia manufacturing companies by using SPSS (Statistical Package for the Social Sciences) 22. To determine and analyze the effects of profitability, size, tangibility, and GDP growth on book leverage of two groups of companies, this research employed multiple linear regression analysis. The test used E-Views (Econometrics Views) 10.0.

The measurement of research and operational variables is explained in the following table. 
Table 1. Scale measurements

\begin{tabular}{lccc}
\hline Variables & Definitions & Indicators & Scale \\
\hline $\begin{array}{l}\text { Dependent } \\
\text { BLEV }\end{array}$ & Book Leverage & (Total Assets/Total Debt) & Ratio \\
Independent & & & \\
PROF & Profitability & (Total EBITDA/Total Assets) & Ratio \\
SIZE & Company size & Log Total Sales & Ratio \\
TANG & Tangibility & Fixed Assets / Total Assets & Ratio \\
GDP & Gross Domestic Product & GDP growth (quarterly \%) & Ratio \\
\hline
\end{tabular}

Source: (Yildirim et al., 2018).

\section{Equation Model}

Independent sample t-test was used to find out the difference of book leverage means between sharia and non-sharia manufacturing companies. The calculation of the value used the following formula:

$$
t=\frac{\overline{\mathrm{X}}_{1}-\overline{\mathrm{X}}_{2}}{\sqrt{\frac{\left(\mathrm{n}_{1}-1\right) \mathrm{S}_{1}{ }^{2}+\left(\mathrm{n}_{2}-1\right) \mathrm{S}_{2}{ }^{2}}{\mathrm{n}_{1}+\mathrm{n}_{2}-2}}\left(\frac{1}{\mathrm{n}_{1}}+\frac{1}{\mathrm{n}_{2}}\right)}
$$

Note:

$\overline{\mathrm{X}}_{1}=$ mean of sample 1

$\overline{\mathrm{X}}_{2}=$ mean of sample 2

$\mathrm{n}_{1}=$ total amount of sample 1

$\mathrm{n}_{2}=$ total amount of sample 2

$\mathrm{S}_{1}=$ standard deviation of sample 1

$\mathrm{S}_{2}=$ standard deviation of sample 2

The regression equation models for sharia (Sy) and non-sharia (nSy) manufacturing companies are as follow:

$$
\begin{aligned}
& \mathrm{BLEV}_{\text {Sy }}=¥_{0}+¥_{1} \mathrm{PROF}_{\text {Sy }}+¥_{2} \mathrm{SIZE}_{\text {Sy }}+¥_{3} \mathrm{TANG}_{\text {Sy }}+¥_{4} \mathrm{PDB}+\mathrm{e}_{1} \\
& \mathrm{BLEV}_{\mathrm{nSy}}=€_{\mathrm{o}}+€_{1} \mathrm{PROF}_{\mathrm{nSy}}+€_{2} \mathrm{SIZE}_{\mathrm{nSy}}+€_{3} \mathrm{TANG}_{\mathrm{nSy}}+€_{4} \mathrm{PDB}+\mathrm{e}_{2} \ldots \ldots \ldots \ldots \ldots \ldots . . .2 \text { ) }
\end{aligned}
$$

Note:

$¥ o$ and $€_{0}$ are constant values for Sy and nSy; $¥_{1}$ and $€_{1}$ are profitability regression coefficient values for Sy and nSy; $¥_{2}$ and $€_{2}$ are company size regression coefficient values for Sy and nSy; $¥_{3}$ and $€_{3}$ are tangibility regression coefficient values for Sy and nSy; and $¥_{4}$ and $€_{4}$ are GDP regression coefficient values for Sy and nSy.

\section{RESULTS}

The result of data collection shows that the number of manufacturing companies listed on the Indonesia Stock Exchange from 2011 to 2017 is fluctuating. There were 154 manufacturing 
companies listed at the end of 2017. Those which met the criteria of the sample were 62 sharia companies and 42 non-sharia ones. The statistical description is as follow:

Table 2. Statistical Test Result of sharia and non-sharia manufacturing companies

\begin{tabular}{llccc}
\hline & & MEAN & MAX & MIN \\
\hline \multirow{2}{*}{ BLEV } & ISSI & 0.40 & 1.22 & 0.04 \\
& NON ISSI & 0.83 & 5.07 & 0.08 \\
\hline \multirow{2}{*}{ SIZE } & ISSI & 6.30 & 8.30 & 2.96 \\
& NON ISSI & 6.22 & 8.80 & 2.81 \\
\hline \multirow{2}{*}{ TANG } & ISSI & 0.33 & 0.89 & 0.00 \\
& NON ISSI & 0.45 & 6.45 & 0.00 \\
\hline \multirow{2}{*}{ PROF } & ISSI & 0.09 & 1.58 & -0.20 \\
& NON ISSI & 0.04 & 3.21 & -0.70 \\
\hline \multirow{2}{*}{ GDP } & ISSI & 5.39 & 6.20 & 4.80 \\
& NON ISSI & 5.39 & 6.20 & 4.80 \\
\hline
\end{tabular}

Source: processed data, 2019

Table 2 shows that sharia and non-sharia manufacturing companies have different BLEV means of 0.40 and 0.83 respectively. The BLEV mean of sharia manufacturing company is under 0.45 , which has fulfilled the regulation of Bapepam LK regarding sharia-based company. The value of BLEV in ISSI (sharia) companies, therefore, still gets chance to be improved. The trade-off theory explains that the increase of debt is suggested if its benefit is greater than its risks. Meanwhile, the agency theory claims that the increase in debt can reduce the agency problem. The increase of debt or BLEV can be done to make use the sharia financial institutions, especially the Islamic banks. The research result by (Friantina, 2019) concludes that non-interest financing can reduce business risks and the risks of financing itself. In addition, (Setiawan, 2019) also concludes that the financing of sharia banking provides various positive roles in many economic sectors, especially in providing employment. Moreover, the above table also shows that the maximum value of BLEV for sharia manufacturing companies is 1.22 and 5.07 for the non-sharia ones. Meanwhile, the minimum values for both groups are 0.04 and 0.08 respectively.

The means of company Size for both groups reach almost similar number, 6.30 for the sharia and 6.22 for the non-sharia. It shows that, in the average, sharia manufacturing companies obtain higher income than the non-sharia ones. The maximum values of Size for both groups are 8.30 and 8.80 while the minimum values are 2.96 and 2.81 respectively.

The means of TANG or tangibility of both groups reach different values; 0.33 for sharia manufacturing companies and 0.45 for the non-sharia. Non-sharia manufacturing companies, in the average, have higher tangibility. It implies that non-sharia manufacturing companies can provide more security in handling assets guarantee for funding debt. Furthermore, the maximum values of Tangibility for both sharia and non-sharia manufacturing companies are 0.89 and 6.45 respectively while the minimum values are 0.00 and 0.00 .

The means of PROF or Return on Asset also reach different values; 0.09 for sharia manufacturing companies and 0.03 for the non-sharia. It shows that, in average, sharia manufacturing companies can obtain higher profits than the non-sharia. The maximum values of both groups are 1.68 and 3.21 while the minimum values are -0.20 and -0.70 respectively. GDP or Gross Domestic Product (D_PDB) of both groups reaches similar mean of 5.39 because they were in the same research period. The maximum value of GDP for both groups is 6.20 while the minimum value is 4.80 . 


\section{Difference Test of Independent Sample T-test}

Table 3. Difference test of independent sample t-test result

\begin{tabular}{ccccc}
\hline No. & $\begin{array}{c}\text { Kinds of } \\
\text { companies }\end{array}$ & $\begin{array}{c}\text { Levene's Test For Equality of } \\
\text { Variance } \\
\text { Sig. }\end{array}$ & $\begin{array}{c}\text { t-test for Equality } \\
\text { Means } \\
\text { Sig (2-tailed) }\end{array}$ & $\begin{array}{c}\text { Composite } \\
\text { Reliability } \\
\text { Means Difference }\end{array}$ \\
\hline 1. & ISSI and Non ISSI & o.ooo & 0.000 & -0.43524 \\
\hline
\end{tabular}

Source: Data processing result of Statistical Package for the Social Sciences (SPSS) 22, 2019.

$\mathrm{H}_{0}$ : There is no significant difference on the capital structure of sharia and non-sharia manufacturing companies.

$\mathrm{H}_{\mathrm{a}}$ : There is a significant difference on the capital structure of sharia and non-sharia manufacturing companies. Hypothesis test result: If Asymp.sig (2-tailed) > 0.05, Ho is accepted; if Asymp.sig (2-tailed) <0.05, Ho is rejected.

Independent Sample T-test result shown in Table 3 finds Sig (2-tailed) $0.000(<0.05)$ due to the Confidence Interval of the Difference of 95\%. Based on the result, Ho is rejected and Ha is accepted. It means there is a significant difference on the capital structure of sharia and non-sharia manufacturing companies.

$\mathrm{H}_{1}$ : There is a significant difference on the capital structure of sharia and non-sharia manufacturing companies

Table. 4 Data Processing Result of Independent Sample T-test (Group Statistics)

\begin{tabular}{lccccc}
\hline No. & $\begin{array}{c}\text { Kinds of } \\
\text { companies }\end{array}$ & $\mathrm{N}$ & Mean & $\begin{array}{c}\text { Std. } \\
\text { Deviation }\end{array}$ & $\begin{array}{c}\text { Std. Error } \\
\text { Mean }\end{array}$ \\
\hline 1. & ISSI & 427 & 0.3954 & 0.18425 & 0.00892 \\
2. & Non ISSI & 294 & 0.8306 & 0.71371 & 0.04162 \\
\hline \multicolumn{5}{l}{ Source: Data processing result of Statistical Package for the Social Sciences (SPSS) 22, 2019. }
\end{tabular}

Data processing result shown in Table 4 finds out that the mean of BLEV or DAR of sharia manufacturing companies (code: ISSI) is 0.3954 . It is significantly different with the one of nonsharia (code: NON ISSI) which reaches 0.8306 . It is also reinforced by Sig (2-Tailed) shown in Tabel 4 of 0.000 .

This result shows that BLEV value in sharia manufacturing companies has complied with the decrees of DSN MUI and Bapepam LK regarding Sharia Securities List Number KEP-208/BL/2012 which implies that the total of interest-based or usury-based debt must not be more than 0.45 . Non-sharia manufacturing companies, on the other hand, do not have certain regulation regarding capital structure decision represented by BLEV. Therefore, it can have a mean value of 0.8306 .

This mean of BLEV on sharia manufacturing companies also shows the application of Pecking Order theory. The portion of capital structure funded by debt is lesser than other capitals which are probably funded by retained earnings or other assets; it tends to be preferred by the management (Myers, 2001). Non-sharia manufacturing companies, however, tend to apply Trade Off theory as (Frank \& Goyal, 2009) say that debt can be continuously used as long as the benefit is still greater than its expenses. 


\section{DISCUSSION}

Table 5. Multiple regression analysis result of sharia manufacturing companies (ISSI)

\begin{tabular}{clcc}
\hline No. & Variable & Coefficient & Prob. \\
\hline 1. & Constanta & 0.742736 & 0.0000 \\
2. & SIZE & -0.052214 & 0.0036 \\
3. & TANG & 0.107816 & 0.0226 \\
4. & PROF & -0.186406 & 0.0004 \\
5. & D_PDB & -0.006859 & 0.4402 \\
\hline
\end{tabular}

Source: Data Processing Result of EViews 10.0 (Econometrics Views 10.0), 2019.

The result of multiple regression analysis equation:

Y1 $(\mathrm{BLEV})_{\mathrm{ISSI}}=0.742736+(-0.052214)(\mathrm{SIZE})+0.107816(\mathrm{TANG})+(-0.186406)(\mathrm{PROF})+$ (- o.006859) (D_GDP)

By applying the coefficient of regression results of each variable as described by the model in Table 5, several results were obtained:

Panel ELGS (Cross-Section random effects) method found the following results:

1. There is a negative coefficient which indicates negative relation between SIZE and ISSI BLEV. The higher the SIZE, the lower the ISSI BLEV. It implies that SIZE becomes the guideline for a company to reduce its debt portion. It is in line with the research result of (Yildirim et al., 2018) which claims that it is only non-sharia companies that use debt as one of the main funding sources for company's capital structure. This finding is also supported by (Haron \& Ibrahim, 2012) in Malaysia as shown in statistical description in Table 2 which shows that the average Size of sharia companies in Malaysia is 6.30. It is bigger that the non-sharia which only reaches the value of 6.22. Sharia companies in Malaysia have greater incomes, bigger size, and tend to generate higher profits too. They have excess funds to be used as internal funds or retained earnings in order to support other future investments. The funds are also used as capital reserves as the main contributor for company's capital structure. Therefore, based on this explanation, $\mathrm{H} 2$ hypothesis can be accepted.

$\mathrm{H}_{2}$ ISSI: The SIZE of company gives significant impact on the capital structure of sharia

2. There is a positive coefficient which indicates positive relation between TANG and ISSI BLEV. The higher the TANG, the higher the ISSI BLEV. It implies that tangibility gives significant impact on BLEV because the profitability value is smaller than 0.05. This finding is different from (Yildirim et al., 2018)'s which says it is only non-sharia companies that show the impact between tangible assets and debt increase as one of the main instruments of capital structure. This research result is in line with Trade Off theory by (Titman \& Wessels, 1988). It says that tangible assets can reduce debt expenses. The significant positive relation also confirms the role of tangible assets in reducing agency costs (De Jong et al., 2008). Based on this, therefore, $\mathrm{H}_{3}$ hypothesis can be accepted.

$\mathrm{H}_{3}$ ISSI: Tangibility gives significant impact on the capital structure of sharia manufacturing companies

3. There is a negative coefficient which implies negative relation between PROF and ISSI BLEV. As the value of PROF increases, the value of ISSI BLEV decreases. It indicates that profitability 
gives significant negative impact on the use of debt as the main funding source in the development of capital structure of sharia manufacturing companies. Greater profits make sharia manufacturing companies reluctant to use debt as one of the instruments in developing capital structure. Increase in profits enables the companies to save more capital for the future, known as retained earnings. They do not need to look for other sources of fund, such as debt, to develop their capital structure (Yildirim et al., 2018) as also said in Pecking Order theory stated by (Myers, 2001). Then, the companies can maintain the profits or incomes to keep financial flexibility. The use of internal funds is preferable because it complies with the existing regulations. It also avoids interest and usury for sharia companies as stated by (Thabet \& Hanefah, 2014) and (Haron \& Ibrahim, 2012). Therefore, $\mathrm{H}_{4}$ hypothesis can be accepted.

$\mathrm{H}_{4}$ ISSI: Profitability gives significant impact on the capital structure of sharia manufacturing companies

4. There is a negative coefficient which indicates negative relations between D_GDP and ISSI BLEV. As the value of D_GDP increases, the value of ISSI BLEV decreases. Seen from the value of profitability of 0.05 (above the level of trust), it can be said that D_GDP, as the macro variable, does not have any impact on the capital structure of sharia manufacturing companies (indicated by ISSI BLEV). The sharia manufacturing companies issue more equity when the economy grows (Yildirim et al., 2018). Besides, there is no empirical evidence which shows that the sharia manufacturing companies consider the macro factor in using debt capital to develop their capital structure. It results on decreasing the companies' leverage shown in BLEV as supported by (Ariff, Taufiq, \& Shamsher, 2008) and (Bokpin, 2009). Therefore, $\mathrm{H}_{5}$ hypothesis is rejected for sharia manufacturing companies.

$\mathrm{H}_{5}$ ISsi: GDP gives significant impact on the capital structure of sharia manufacturing companies.

Table 6. Multiple regression analysis result of non-sharia manufacturing companies (NON ISSI)

\begin{tabular}{cllc}
\hline No. & \multicolumn{1}{c}{ Variable } & Coefficient & Prob. \\
\hline 1. & Constanta & 01.951521 & 0.0000 \\
2. & SIZE & -0.276370 & 0.0000 \\
3. & TANG & 0.125908 & 0.0002 \\
4. & PROF & -0.145819 & 0.0124 \\
5. & D_PDB & -0.086375 & 0.0002 \\
\hline
\end{tabular}

Source: Data processing result by EViews 10.0 (Econometrics Views 10.0), 2019.

Y2 $(\text { BLEV) })_{\text {NON ISSI }}=2.951521+(-0,276370)($ SIZE $)+0.125908($ TANG $)+0.145819(\mathrm{PROF})$

$$
+(-0.086375)\left(D \_G D P\right)
$$

By applying the coefficient of regression results of each variable as described by the model in Table 6, several results were obtained:

Panel ELGS (Cross-Section random effects) method found the following results:

1. There is a negative coefficient which indicates negative relation between SIZE and NON ISSI BLEV. As the value of SIZE increases, the value of NON ISSI BLEV decreases. Profitability value of 0.000 shows significant impact on the relation of SIZE and NON ISSI BLEV. The big size of the companies results on high incomes for them. It is contrary to the result of (Yildirim et al., 2018) which discovers positive relation toward BLEV on non- sharia companies. The bigger the 
SIZE of company, the smaller the risk of bankruptcy, and the bigger the debt it makes. Nonsharia manufacturing companies in Indonesia tend to have lower income compared to the sharia one. It means that the companies do not own more funds to conduct future investment so they have to fund their capital structure by debt. It is in line with the research conducted by (Haron \& Ibrahim, 2012). From the above explanation, therefore, H2 NON ISSI hypothesis can be accepted.

H2 NON ISSI: Size of company gives significant impact on the capital structure of non-sharia manufacturing companies

2. There is a positive coefficient which indicates positive relation between TANG and NON ISSI BLEV. The higher the TANG, the higher the NON ISSI BLEV. Non-sharia manufacturing companies tend to use debt to develop their capital structure because of the positive relation between tangible assets and BLEV. Tangible assets can give more security and trust to lenders or credit financing because they can be used as credit guarantee. It is in line with the research result by (Yildirim et al., 2018) which say that tangible assets is one of the consistent determinants in relation to leverage. This result is also supported by (Johnson, 2003) and (Kayo \& Kimura, 2011). According to (De Jong et al., 2008), the positive relation between tangibility and leverage enforces that tangible assets can reduce agency costs and increase company's leverage. Therefore, $\mathrm{H}_{3}$ NON ISSI can be accepted.

$\mathrm{H}_{3}$ NON ISSI: Tangibility gives significant impact on the capital structure of non-sharia

3. There is a positive coefficient which implies positive relation between PROF and NON ISSI BLEV. The higher the PROF, the higher the NON ISSI BLEV. According to the research result, the capital structure of non-sharia manufacturing companies funded by debt is strongly influenced by profitability. Thus, the higher the profitability, the bigger the leverage portion as the constituent element of capital structure of non-sharia manufacturing companies. This finding is in line with a result by (Hamidy et al., 2014). It is also supported by (Jensen \& Meckling, 1976) who claim the importance of using debt to improve company performance. It is also stated in agency theory that the decision of company's capital structure is closely related to dividend policy. Therefore, $\mathrm{H}_{4}$ NON ISSI can be accepted.

$\mathrm{H}_{4}$ NON IssI: Profitability gives significant impact on the capital structure of non-sharia manufacturing companies

4. There is a negative coefficient which implies negative relation between D_GDP and NON ISSI BLEV. As the value of D_GDP increases, the value of NON ISSI BLEV decreases. According to existing research results, profitability shows the value of 0.000 which means that D_GDP gives significant impact on BLEV of non-sharia manufacturing companies. It indicates that the capital structure of non-sharia manufacturing companies is determined by considering the macro factor, one of which is D_GDP. Thus, the growth of state incomes is in lines with Pecking Order theory which affects the decline in debt financing for non-sharia manufacturing companies (Yildirim et al., 2018). Furthermore, according to (Yildirim et al., 2018), the finding also indicates that non-sharia manufacturing companies issue more equity as the economy grows. 


\section{CONCLUSION}

This research aims to find out 1) the difference between the capital structure of sharia and nonsharia manufacturing companies, and 2) the determinant factors that influence it. The research discovers that there is a significant difference between Mean BLEV or DAR of sharia (code: ISSI) and non-sharia (code: NON ISSI) manufacturing companies. The result indicates that BLEV of sharia manufacturing companies has complied with the decrees of DSN MUI and Bapepam LK regarding Sharia Securities List Number KEP-208/BL/2012which require that the total of interestbased or usury-based debt is not more than 0.45 . Meanwhile, the non-sharia does not have certain regulation regarding capital structure decision; therefore, the value of their BLEV can be above standard.

Moreover, almost all determinant factors give significant impact on the capital structure of sharia manufacturing companies. It is only D_GDP which does not give impact since the probability is greater than the standard of trust. Meanwhile, all determinant factors give significant impact on the capital structure of non-sharia one.

Trade Off theory and Pecking Order theory are two theories used by manufacturing companies in Indonesia. The sharia manufacturing companies tend to apply Pecking Order theory because they use retained earnings and their own capital to develop their capital structure. The regulation imposed on sharia manufacturing companies forces the management to limit the use of usurybased debt. Meanwhile, the non-sharia tends to use Trade Off theory because they still get benefit from the use of debt to develop their capital structure. Besides, this group of company is more flexible because they do not have certain regulation which limits them to use interest-based debt for their capital structure.

\section{REFERENCES}

Ahmed, H. (2007). Issues in Islamic corporate finance: capital structure in firms. Retrieved from https://pdfs.semanticscholar.org/865e/f5dde4c756cceb8047fdoao67677eeb5dfdb.pdf

Ariff, M., Taufiq, H., \& Shamsher, M. (2008). How capital structure adjusts dynamically during financial crises. Corporate finance review, 13(3), 11-24.

Baharudin, A., \& Sy, S. (2015). Debt and Corporate Revenues in Criteria and Issuing Sharia Securities Perspective of Sharia Business Law,Thesis, Program Studi Hukum Islam, Universitas Islam Sunan Kalijaga, Yogyakarta.

Bokpin, G. A. (2009). Macroeconomic development and capital structure decisions of firms: Evidence from emerging market economies. Studies in economics and finance, 26(2), 129-142. doi: 10.1108/10867370910963055

Copeland, T. E., \& Weston, J. F. (1988). Financial Theory and Corporate Policy.

Damodaran, A. (2012). Investment valuation: Tools and techniques for determining the value of any asset (Vol. 666). US: John Wiley \& Sons.

De Jong, A., Kabir, R., \& Nguyen, T. T. (2008). Capital structure around the world: The roles of firm-and country-specific determinants. Journal of Banking \& Finance, 32(9), 1954-1969. doi: 10.1016/j.jbankfin.2007.12.034

Frank, M. Z., \& Goyal, V. K. (2009). Capital structure decisions: which factors are reliably important? Financial management, 38(1), 1-37. doi: 10.1111/j.1755-053X.2009.01026.x

Friantina, Y. (2019). Assessing the Indonesian Banking Risk: A Comparative Study between Islamic and Conventional Banks. International Journal of Applied Business Research, 1(01), 16-30. doi:

10.35313/ijabr.v1io1.37 
Hamidy, R. R., Wiksuana, I. G. B., \& Artini, L. G. S. (2014). Pengaruh struktur modal terhadap nilai perusahaan dengan profitabilitas sebagai variabel intervening pada perusahaan properti dan real estate di bursa efek Indonesia. E-Jurnal Ekonomi dan Bisnis Universitas Udayana.

Haron, R., \& Ibrahim, K. (2012). Target capital structure and speed of adjustment: Panel data evidence on Malaysia Shariah compliant securities. International Journal of Economics, Management and Accounting, 2O(2).

Jensen, M. C., \& Meckling, W. H. (1976). Theory of the firm: Managerial behavior, agency costs and ownership structure. Journal of financial economics, 3(4), 305-360. doi: 10.1016/0304$405 \mathrm{X}(76) 90026-\mathrm{X}$

Johnson, S. A. (2003). Debt maturity and the effects of growth opportunities and liquidity risk on leverage. The Review of Financial Studies, 16(1), 209-236.

Kayo, E. K., \& Kimura, H. (2011). Hierarchical determinants of capital structure. Journal of Banking \& Finance, 35(2), 358-371. doi: 10.1016/j.jbankfin.2010.08.015

Kieso, D. E., Weygandt, J. J., \& Warfield, T. D. (2019). Intermediate accounting. US: John Wiley \& Sons.

Myers, S. C. (2001). Capital structure. Journal of Economic perspectives, 15(2), 81-102.

Pawet, M., Dmytro, O., \& Ryszard, O. (2018). Financial restructuring and target capital structure: An iterative algorithm for shareholder value maximization. Review of Accounting and Finance, 17(2), 280-294. doi:10.1108/RAF-01-2017-0001

Raul, S. (2008). Capital structure decisions: research in Estonian non-financial companies. Baltic Journal of Management, 3(1), 55-70. doi:10.1108/17465260810844266

Saurabh, C., \& K., S. A. (2015). Determinants of capital structure: an empirical evaluation from India. Journal of Advances in Management Research, 12(1), 3-14. doi:10.1108/JAMR-08-2014-0051

Setiawan, I. (2019). The Role of Islamic Banking in the Development of Economic Sectors in Indonesia. International Journal of Applied Business Research, 1(02), 88-99. doi: 10.35313/ijabr.voio.70

Thabet, O. B., \& Hanefah, M. M. (2014). Capital Structure in Islamic Capital Markets: Evidences from Bursa Malaysia. Paper presented at the Proceedings of the Australian Academy of Business and Social Sciences Conference.

Titman, S., \& Wessels, R. (1988). The determinants of capital structure choice. The Journal of finance, 43(1), $1-19$.

Varun, D. (2014). Agency theory, capital structure and firm performance: some Indian evidence. Managerial Finance, 4o(12), 1190-1206. doi:10.1108/MF-10-2013-0275

Yildirim, R., Masih, M., \& Bacha, O. I. (2018). Determinants of capital structure: evidence from Shari'ah compliant and non-compliant firms. Pacific-Basin Finance Journal. 